\title{
A Longitudinal Study of BNT162b2 Vaccine-Induced Humoral Response and Reactogenicity in Health Care Workers with Prior COVID-19 Disease
}

Departments of Thoracic Medicine and Surgery ${ }^{1}$, Anatomy ${ }^{2}$, Biomedical Education and Data Science ${ }^{3}$ and Emergency Medicine 4

Lewis Katz School of Medicine at Temple University

Philadelphia PA 19140

Steven G. Kelsen ${ }^{1}$, Alan S. Braverman ${ }^{1,2}$, Mark O. Aksoy ${ }^{1}$, Jacob A. Hayman ${ }^{1}$, Puja Patel ${ }^{1}$, Charu Rajput ${ }^{1}$, Huaqing Zhao ${ }^{3}$, Susan G. Fisher ${ }^{3}$, Michael R. Ruggieri Sr. ${ }^{2}$ and Nina T. Gentile ${ }^{4}$

Address Correspondence to:

Steven G. Kelsen MD

Room 735 Parkinson Pavilion

Temple University Hospital

3401 N. Broad St.

Philadelphia PA 19140

215-707-2237

kelsen@temple.edu 
medRxiv preprint doi: https://doi.org/10.1101/2021.03.18.21253845; this version posted July 31, 2021. The copyright holder for this preprint (which was not certified by peer review) is the author/funder, who has granted medRxiv a license to display the preprint in perpetuity. It is made available under a CC-BY-NC-ND 4.0 International license .

\section{ABSTRACT}

Background: Current recommendations in the United States are that subjects with a previous history of COVID-19 disease receive the full 2 dose mRNA vaccine regimen. We tested the hypothesis that humoral immune responses and reactogenicity to a SARS-CoV-2 mRNA vaccine (BNT-162b2) differ qualitatively and quantitatively in subjects with prior SARS-CoV-2 infection versus infection-naïve subjects.

Methods: Health care workers $(n=61)$ from a single academic institution with and without prior COVID-19 received two $30 \mu \mathrm{g}$ doses of BNT162b2 vaccine 3 weeks apart. The COVID group $(n=30)$ received vaccine approximately 7 months post infection. IgG antibody against the Spike receptorbinding domain (RBD), serum neutralizing activity and vaccine adverse reactions were assessed every 2 weeks for 56 days after the $1^{\text {st }}$ injection. A longitudinal design and long study duration allowed the onset, maximum response and initial decay rate of Spike IgG antibody to be assessed in each subject. In addition, Spike lgG antibody levels are expressed as $\mu \mathrm{g} / \mathrm{mL}$ to provide normal values for clinical decision making.

Findings: Spike IgG responses were highly variable in both groups. However, the COVID group manifested rapid increases in Spike IgG antibody and serum neutralizing activity post $1^{\text {st }}$ vaccine dose but little or no increase in Spike IgG or serum neutralizing activity after the $2^{\text {nd }}$ dose. In fact, Spike IgG was maximum prior to the $2^{\text {nd }}$ dose in $36 \%$ of the COVID group and $0 \%$ of controls. Peak IgG antibody was lower but appeared to fall more slowly in the COVID than in the control group. Finally, adverse systemic reactions e.g., fever, headache and malaise, after both the $1^{\text {st }}$ and $2^{\text {nd }}$ injection were more frequent and lasted longer in the COVID group than in the control group.

Conclusions: Health care workers with prior COVID-19 demonstrate a robust, accelerated humoral immune response to the $1^{\text {st }}$ dose of the COVID-19 mRNA vaccine but attenuated response to the $2^{\text {nd }}$ dose. They also experience greater reactogenicity than controls. Accordingly, subjects with prior COVID-19 may require only a single dose of vaccine. 
medRxiv preprint doi: https://doi.org/10.1101/2021.03.18.21253845; this version posted July 31, 2021. The copyright holder for this preprint (which was not certified by peer review) is the author/funder, who has granted medRxiv a license to display the preprint in perpetuity. It is made available under a CC-BY-NC-ND 4.0 International license .

\section{INTRODUCTION}

Vaccination against the SARS-CoV-2 virus affords a way to rapidly achieve widespread, protective immunity of the uninfected population and thus end the COVID-19 pandemic. In fact, phase $2 / 3$ clinical trials of the "Pfizer"-BNT162b2 and "Moderna"-mRNA-1273 mRNA vaccines now in use, demonstrate $90-95 \%$ protection against SARS-CoV-2 infection and $100 \%$ effectiveness in preventing severe COVID-19 disease, e.g., hospitalization or death. ${ }^{1-5}$ Similar protective efficacy of the Pfizer BNT162b2 vaccine has been reported in a country-wide population study in Israel. ${ }^{3}$

Public health authorities in the US recommend full vaccination including both doses of the two dose regimen mRNA vaccines for all those over the age of 12 years including those with prior SARS-CoV-2 infection or COVID-19 disease. ${ }^{6}$ Interestingly, this recommendation has been made despite the fact that trials of both COVID-19 mRNA vaccines excluded volunteers with a history of COVID-19 disease and most subjects post COVID-19 have durable immune memory. ${ }^{7-11}$ Moreover, the rate of SARSCoV-2 re-infection in the 15 months since the pandemic started has been quite low..$^{12-14}$

Of interest in this regard, several studies have demonstrated that subjects with prior SARS-CoV-2 infection / COVID-19 disease exhibit rapid and robust humoral and cell-mediated immune responses to a single dose of a two dose mRNA vaccine regimen. ${ }^{15-23}$ Moreover, responses of those with prior SARS-CoV-2 infection to the $1^{\text {st }}$ dose greatly exceed the responses of infection-naïve subjects. This observation has led to the suggestion that a single dose of a COVID mRNA vaccine may be sufficient to provide adequate protection against infection for subjects with prior SARS-CoV-2 infection. ${ }^{18,24}$ Given the scarcity of vaccines in most of the world, it has been suggested that subjects with a history of prior SARS-CoV-2 infection receive only 1 dose of the vaccine. ${ }^{18,20,22}$ In this approach, the second dose would be withheld until some future date as needed.

In contrast to the considerable available data defining the response to the 1st dose of an mRNA vaccine of SARS-CoV-2 infected / COVID-19 disease subjects, little or no information is available regarding their response to the $2^{\text {nd }}$ dose of vaccine given at the standard 3 to 4 week dosing interval. Anecdotal data, however, suggest that after a 2 nd dose of an mRNA vaccine at least some subjects with prior COVID-19 disease exhibit reductions in protective IgG antibody levels and circulating memory B and T cells. ${ }^{19}$

Accordingly, this longitudinal study examined the hypothesis that the time course and magnitude of the humoral immune response and reactogenicity induced by a full, two dose mRNA vaccination regimen differed quantitatively in subjects with prior COVID-19 disease versus infection - naïve subjects. Specifically, we examined the level of anti-Spike IgG antibody and serum neutralizing activity serially at fixed points in time i.e., 2 week intervals, for 56 days after the 1 st and 35 days after the $2^{\text {nd }}$ injection in SARS-CoV-2 infected and infection - naïve health care workers from the same academic health care center. To avoid possible confounding effects of differences in immune potency and reactogenicity between mRNA vaccines, a single vaccine i.e., Pfizer BNT162b2, was used. ${ }^{25}$

Our results indicate that Spike IgG antibody levels and serum neutralizing activity in response to BNT162b2 vaccine is time-dependent and that subjects with prior COVID-19 increase more rapidly, but reach lower peak levels and appear to fall more slowly than in infection-naïve subjects. Our data also represent the first available set of time-dependent normal values for Spike IgG antibody induced by BNT162b2 in normal adults with and without prior COVID-19.

\section{METHODS}

Subjects recruited $(n=61)$ into this vaccine study represented a subset of a larger cohort of healthcare workers (i.e., physicians, nurses, respiratory therapists or other ancillary health care personnel; 
medRxiv preprint doi: https://doi.org/10.1101/2021.03.18.21253845; this version posted July 31, 2021. The copyright holder for this preprint (which was not certified by peer review) is the author/funder, who has granted medRxiv a license to display the preprint in perpetuity. It is made available under a CC-BY-NC-ND 4.0 International license .

$\mathrm{n}=281$ ) participating in a surveillance study of SARS-CoV-2 Spike IgG seropositivity in our multihospital Health System. Subjects in the vaccine sub-study agreed to have blood samples drawn at 2week intervals for 56 days following the initial dose of the BNT162b2 mRNA vaccine. Subjects completed a questionnaire detailing their history of SARS-CoV-2 infection / COVID-19 disease, job description, demographics and comorbidities. The study was approved by our Institutional Review Board.

Subjects in the SARS-CoV-2 infection / COVID-19 positive group (COVID group; $\mathrm{n}=30$ ) had a documented history of COVID-19 with a positive nasopharyngeal swab for virus RNA or were seropositive for IgG antibody against the Spike or nucleocapsid proteins. Subjects in the SARSCoV-2 infection naïve group (control group; $n=31$ ) did not have: COVID-19 illness; viral RNA detected by PCR testing; and were IgG seronegative for the Spike and nucleocapsid proteins.

The BNT162b2 vaccine was given to all subjects as currently recommended i.e., two, $30 \mu \mathrm{g}, 0.5 \mathrm{ml}$ intramuscular injections given 3-weeks apart. Vaccine administration in both groups took place from December 16, 2020 until April 2, 2021. Blood samples were obtained at 14, 28, 42, and 56 days post $1^{\text {st }}$ dose. Those sampling intervals were based on the BNT162b2 phase 1 trial which demonstrated maximal immune responses by day $42 .{ }^{5}$

\section{SARS-CoV-2 Antibody}

Serum SARS-CoV-2 Spike receptor binding domain (RBD) IgG antibodies were quantified by a twostep immunoassay using the Beckman Coulter, Access ${ }^{\circledR}$ microparticle-based system run on a high

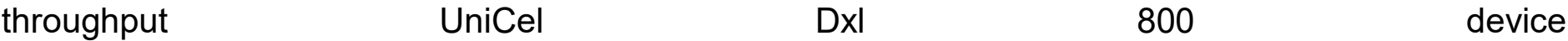
(https://www.beckmancoulter.com/en/products/immunoassay/access-sars-cov-2-igg-ii-assay). This assay uses antigen-coated paramagnetic particles which when mixed with subject serum create an antigen-antibody complex. Anti-human lgG acridinium-labeled conjugate is then added to create a chemiluminescent signal measured as relative light units (RLU). Serum samples were diluted 1:10 and 1:20 to ensure that signals remained in the linear range of the standard curve. This system has a 4 order of magnitude dynamic range. ${ }^{26,27}$

A recent study by Bartsch et al indicates that Spike RBD IgG antibody concentrations when present above a critical threshold, correlate with other aspects of immune function such as serum neutralization activity, opsonization activity and T-cell activation responses to SARS-CoV-2 virus antigen. ${ }^{28}$ As such, the concentration of Spike lgG antibody seems to reflect the overall activity of the immune system. Accordingly, we used a recombinant, human IgG1 monoclonal SARS-CoV-2 Spike RBD antibody, Clone CR3022, produced in Nicotiana benthamiana (BEI Resources, Manassas, VA) to convert RLU values to $\mu \mathrm{g} / \mathrm{mL}$ protein as previously described. ${ }^{28,29}$

SARS-CoV-2 nucleocapsid IgG antibody was also measured to detect possible superimposed SARSCoV-2 infection during the 56 days post vaccination. Nucleocapsid IgG antibody was measured using the Abbott Alinity system which is also a twostep, microparticle, chemiluminescent immunoassay (https:// www.corelaboratory.abbott/us/en/offerings/segments/infectious-disease/sarscov-2).

\section{Neutralization Assay}

Serum neutralization assays were performed as previously described using luciferase - expressing, lentiviral particles pseudotyped for the SARS-CoV-2 Spike protein and HEK-293T cells overexpressing the ACE2 receptor. ${ }^{30,31}$ The Spike protein was from SARS-CoV-2 strain Wuhan-Hu1 as previously described by Crawford et al (see Supplementary Methods and Figures S3 and S4 for 
medRxiv preprint doi: https://doi.org/10.1101/2021.03.18.21253845; this version posted July 31, 2021. The copyright holder for this preprint (which was not certified by peer review) is the author/funder, who has granted medRxiv a license to display the preprint in perpetuity. It is made available under a CC-BY-NC-ND 4.0 International license .

further details). ${ }^{30}$ Neutralizing activity was expressed as the serum dilution which produced $50 \%$ inhibition $\left(\mathrm{IC}_{50}\right)$ of pseudo-particle entry. IC $\mathrm{C}_{50}$ was calculated using sigmoidal 4 factor polynomial, non-linear regression in GraphPad Prism version 9.

\section{Vaccine Reactogenicity}

The duration and severity of local and systemic reactions to the vaccine which occurred within 7 days of each injection were assessed using a standard questionnaire administered at the time of each blood draw. The severity of solicited local (pain / tenderness) and systemic reactions (fever, malaise, headache) were scored from 0 (none) to 10 (most severe) with scores $\geq 6$ classified as severe.

\section{Statistical Analysis}

Continuous measures within groups were expressed as mean \pm 1 standard error (SE). Comparison of categorical variables between groups was assessed by Fisher Exact test and within groups by McNemar's Test for paired comparisons. Comparison of changes in antibody levels over time, or between the COVID and control groups was assessed by linear mixed-effects models for repeated measures. Statistical significance of differences was accepted at the $p<0.05$ level.

\section{RESULTS}

\section{Study Population}

Demographic characteristics of COVID $(n=30)$ and control groups $(n=31)$ are shown in Table 1 . The two groups were well matched for age, gender and ethnicity. Mean age in the COVID and control groups was 47 years and 45 years, respectively $(p>0.80)$. Gender was male in $50 \%$ of the COVID and $52 \%$ of the control group $(p>0.80)$. Most subjects were Caucasians ( $80 \%$ and $77 \%$, in the COVID and control groups, respectively, $p>0.90)$ but African-Americans and Asians were also included in both groups.

Clinical features of the COVID illness are shown in Table 2. Most subjects (93\%) were symptomatic; $7 \%$ were asymptomatic. Four subjects (13\%) had COVID-pneumonia. Two subjects $(7 \%)$ were hospitalized.

Pre-vaccination levels of Spike RBD IgG or nucleocapsid IgG antibodies were elevated in $81 \%$ of subjects in the COVID group and none of the controls (Figure S1).

On average, COVID subjects received the first dose of vaccine $\sim 7$ months post onset of symptoms (POS) (mean $201 \pm 16$ SE days; range = 25 to 332 days) (Table 2). In fact, 58\% of the COVID group received the first vaccine dose more than 7 months POS (i.e., $>220$ days).

\section{Antibody Responses to Vaccine}

Spike RBD antibody levels at each time point post vaccination are shown in Figure 1 upper and lower panels as arbitrary units and in Table 3 as mcg protein / $\mathrm{mL}$.

The time course and magnitude of the Spike RBD antibody response differed greatly across individuals in both groups (Figure 1 lower) but were significantly different in the COVID and control groups as a whole ( $p<0.0001$ by linear mixed effects; Figure 1 upper). In the COVID group, Spike RBD IgG increased more rapidly, peaked earlier but appeared to fall more slowly than in the control group.

Specifically, in the COVID group, Spike IgG antibody at day 14 post $1^{\text {st }}$ injection increased significantly from the pre-vaccine level $(p<0.0001)$ (Table 3). Thereafter, little or no increase in Spike IgG occurred in the COVID group and IgG values at subsequent time points were not significantly 
medRxiv preprint doi: https://doi.org/10.1101/2021.03.18.21253845; this version posted July 31, 2021. The copyright holder for this preprint (which was not certified by peer review) is the author/funder, who has granted medRxiv a license to display the preprint in perpetuity.

It is made available under a CC-BY-NC-ND 4.0 International license .

different from the day 14 value ( $p>0.05$ for all later time points compared with day 14). In the COVID group, Spike IgG levels peaked at day 14 in 36\%; at day 28 in 52\%; at day 42 in 12\%; and at day 56 in $0 \%$ of subjects (Figure 1 lower panel).

In contrast, in the control group, increases in Spike IgG at day 14 were not statistically different from the pre-vaccine value $(p>0.20)$ and levels were significantly less than in the COVID group $(p<0.0002)$. Thereafter, Spike IgG levels increased markedly between day 14 and day 28 in the control group $(p<0.0001$ for comparison of the 2 time points). In the control group, Spike IgG peaked at day 14 in $0 \%$; at day 28 in 60\%; at day 42 in 37\%; and at day 56 in 3\% of subjects. Of note, peak Spike IgG values were significantly greater in the control than the COVID group $(p<0.0002)$ (Table 3 ).

Spike IgG antibody levels declined from peak values in both groups but appeared to do so more slowly in the COVID group. In particular, from day 42 to day 56, Spike IgG fell significantly in the control group $(p<0.001)$ but not in the COVID group $(p>0.90)$.

The considerable variation in the interval between SARS-CoV-2 illness and vaccination i.e., post onset symptoms (POS), in the COVID group, i.e. 25 to 332 days (Table 2) did not appear to explain differences in peak Spike IgG levels. In fact, the peak Spike IgG level was unrelated to the interval between $P O S$ and vaccination (Figure 2; $R^{2}=0.01$ by linear regression).

In contrast to Spike IgG, nucleocapsid IgG antibody, which was assessed to detect the unlikely possibility of superimposed SARS-CoV-2 infection during the study, was undetectable in the control group and declined progressively in the COVID group (Figure S2). Individual nucleocapsid IgG values are also shown in Figure S2 (lower panel).

\section{Serum Neutralization Activity}

Pre-vaccination, serum neutralization activity was modestly elevated in the COVID versus control group (IC50 $7 \times 10^{-3}$ dilution and $2 \times 10^{-2}$ dilution, respectively) but was not statistically significantly different in the 2 groups ( $p=0.20$ by two way ANOVA) (Figure 3 upper panel).

At day 14 post $1^{\text {st }}$ injection, neutralizing activity increased $\sim 17$ fold in the COVID group but was unchanged in the control group (Figure 3 middle panel). Specifically, IC 50 was $4 \times 10^{-4}$ dilution in the COVID group and $1 \times 10^{-2}$ dilution in controls i.e., $\sim 25$ fold greater in the COVID group $(p<0.03$ by two way ANOVA).

At day 42 post $1^{\text {st }}$ injection, however, neutralizing activity in the COVID group was essentially unchanged from the 14 day value (i.e., IC50 $4 \times 10^{-4}$ dilution and $5 \times 10^{-4}$ dilution for days 14 and 42 , respectively). In contrast, neutralizing activity increased markedly in the control group from the day 14 value (i.e., IC $501 \times 10^{-2}$ dilution and $3 \times 10^{-4}$ dilution for days 14 and 42, respectively) (Figure 3 lower panel). As a result, there were no differences in neutralizing activity in the COVID and control groups at day 42 ( $p=0.11$ by two way ANOVA for the 2 curves).

\section{Vaccine Reactogenicity}

In general, systemic reactogenicity was greater in the COVID than the control group. Specifically, after the first injection, systemic symptoms (i.e., fever, headache, malaise/fatigue) were more frequent ( $p<0.05$ for each by Fisher's exact test) and lasted longer ( $p<0.001$ by unpaired test) in COVID than in control subjects (Fig. 4A and B). The use of antipyretics and/or analgesics was also more frequent in COVID ( $p<0.05$ by Fisher Exact test) (Fig. 4B).

In contrast, local reactions (i.e., pain and tenderness) occurred in most subjects ( $\geq 80 \%$ ) and with similar frequency in both groups $(p=N S)$ (Fig. 4A). 
medRxiv preprint doi: https://doi.org/10.1101/2021.03.18.21253845; this version posted July 31, 2021. The copyright holder for this preprint (which was not certified by peer review) is the author/funder, who has granted medRxiv a license to display the preprint in perpetuity.

It is made available under a CC-BY-NC-ND 4.0 International license .

After the second injection, fever and headache were again more frequent in the COVID group ( $p<0.05$ for both) and systemic symptoms continued to last longer $(p<0.01)$ (Fig. 4A and B). Local reactions to the $2^{\text {nd }}$ injection were similar in frequency and severity in both groups (Fig. 4A).

All reactions resolved within 7 days without need for medical attention.

\section{DISCUSSION}

This study in a cohort of healthcare workers in a single academic medical center was designed to test the hypothesis that humoral immune responses and reactogenicity to a SARS-CoV-2 mRNA vaccine (BNT-162b2) differ in subjects with and without prior SARS-CoV-2 infection. This hypothesis was based on observations that subjects with prior SARS-CoV-2 infection have long-lasting memory B-cell and T-cell based immunity to the Spike protein immunogen in the vaccine. ${ }^{7,10}$ Accordingly, to define the vaccine-induced, humoral immune response and reactogenicity, subjects were studied at 2-week intervals for 56 days post initial vaccination. The longitudinal design and length of the study allowed the onset, maximum response and initial decay rate of Spike IgG antibody to be assessed in each subject.

Our results indicate that the time course and magnitude of the Spike RBD IgG and serum neutralizing responses to the vaccine differed in the two groups. Specifically, in the COVID group, Spike IgG antibody increased more rapidly, but reached lower peak levels and seemed to fall more slowly i.e., the response was "flatter," in the COVID group than in the infection-naïve, control group. In fact, a large percentage of the COVID group (36\%) achieved maximum Spike IgG antibody responses 14 days after the initial injection and did not respond to the $2^{\text {nd }}$ injection. Moreover, for the COVID group as a whole, serum neutralizing activity was maximum at day 14 and did not increase with the 2nd vaccine. Accordingly, serum neutralizing activity mirrored the Spike IgG antibody response.

In contrast to changes in Spike IgG, nucleocapsid IgG was undetectable in the control group and decreased progressively over the observation period in the COVID group. This finding rules out the remote possibility that superimposed SARS-CoV-2 infection in either group during the vaccination period may have confounded the results.

The frequency and duration of systemic reactions to the BNT-162b2 vaccine were heightened in subjects with prior SARS-CoV-2-infection although none were serious. Heightened systemic reactions in the COVID group were present with both the $1^{\text {st }}$ and $2^{\text {nd }}$ injection but were most apparent after the 1 st injection.

The rapid, robust Spike IgG response to the first dose of vaccine in the COVID group more than 7 months after prior infection and attenuated response to the second dose likely represents an anamnestic response mediated by long duration memory B and T cells. ${ }^{7,10,17}$ In fact, most SARSCoV-2 infected individuals continue to have circulating memory B-cells, bone marrow plasma cells, $\mathrm{T}$ follicular helper cells and CD4 and CD8 Th1-cells present for 8 to 11 months post infection. ${ }^{7,8,10}$ Preexisting immune memory against the Spike immunogen in the COVID group may also explain the heightened vaccine reactogenicity.

Our study has a number of strengths. First, the longitudinal study design with fixed 2-week sampling intervals and long duration allowed us to define the onset, peak and initial decay rate of Spike IgG antibody in both groups despite the considerable individual variability. 
medRxiv preprint doi: https://doi.org/10.1101/2021.03.18.21253845; this version posted July 31, 2021. The copyright holder for this preprint (which was not certified by peer review) is the author/funder, who has granted medRxiv a license to display the preprint in perpetuity. It is made available under a CC-BY-NC-ND 4.0 International license.

Second, the COVID and control groups were well-matched for age and gender. This is important since age and gender determine immune responses to many vaccines. ${ }^{32,33}$ Accordingly, differences in vaccine responses observed in the 2 groups in this study are not explainable by differences in gender or age.

Third, accepted methods were utilized to assess Spike RBD IgG antibody levels. ${ }^{26,27,34}$ In fact, antibody levels were expressed in absolute units (i.e., mcg protein / $\mathrm{mL}$ ) as well arbitrary units (i.e., chemiluminescence units). ${ }^{28,29}$ We specifically chose to express the Spike IgG response as mcg protein / $\mathrm{mL}$ to allow the "normal" vaccine response of healthy subjects to be available for medical decision making. That is, Spike IgG levels generated in a healthy population at discrete points in time post-vaccination are now available to assess the adequacy of the vaccine response in subjects with co-morbid medical conditions which could impair the immune response (e.g., solid organ transplant). ${ }^{35}$

We assessed the serum neutralizing activity in the two groups using an accepted pseudotyped lentivirus neutralization assay since not all antibodies targeting the RBD are neutralizing. ${ }^{30,36,37}$ Conversely, antibodies against Spike protein epitopes outside the RBD may also be neutralizing. ${ }^{36,37}$ Accordingly, serum neutralizing activity represents a more comprehensive way of assessing the humoral immune response. ${ }^{34}$

Fourth, since both the immune response and adverse effects induced are vaccine-type dependent, a single, extensively used vaccine i.e., BNT162b2, was studied to avoid confounding effects on the responses observed. ${ }^{25}$

Our study also has limitations. First, while our data over 56 days post $1^{\text {st }}$ injection suggest that Spike IgG antibody levels may fall more slowly in the COVID group than in infection naïve subjects, the long-term IgG antibody level was not defined in this study. This is of importance since vaccine protection depends on the sustained antibody level. ${ }^{32}$ Additional time points will be needed in this regard.

Second, we studied subjects in the COVID group at a single time point i.e., $\sim 7$ months post infection. Although no relationship between the interval post infection and peak Spike IgG antibody level was evident in the COVID group, it would be desirable to obtain data at additional intervals post infection. Also, our COVID group consisted almost entirely of symptomatic individuals (93\%) biased toward the severe end of the spectrum (several had pneumonia and were hospitalized). Since the intensity of the humoral and cell-mediated responses to SARS-CoV-2 correlate directly with the number and severity of COVID-19 symptoms, subjects with milder forms of SARS-CoV-2 infection e.g., asymptomatic or pauci-symptomatic infection may respond differently. ${ }^{19,38}$

Third, our neutralizing assay utilized the original Wuhan-Hu-1 strain for the Spike protein as the neutralizing antibody target. Accordingly, our serum neutralizing activity study did not measure effectiveness against the more recent SARS-CoV-2 variants which are of considerable public health concern.

Finally, we did not assess other IgG antibody-mediated effects in addition to neutralization (e.g., opsonization, complement fixation and NK cell activation). However, in this regard, Bartsch at al observed in a cohort of subjects convalescing from SARS-CoV-2 infection that increasing levels of IgG Spike RBD antibody above a threshold of $\sim 0.5-1.0 \mathrm{mcg} / \mathrm{mL}$ indicate broad activation of the adaptive and innate immune system. ${ }^{28}$ Specifically, Bartsch observed that Spike RBD IgG antibody levels above this threshold correlate directly with increasing neutrophil phagocytosis, complement fixation and T-cell responses to SARS-CoV-2 Spike antigens. The maximal level of Spike IgG 
medRxiv preprint doi: https://doi.org/10.1101/2021.03.18.21253845; this version posted July 31, 2021. The copyright holder for this preprint

(which was not certified by peer review) is the author/funder, who has granted medRxiv a license to display the preprint in perpetuity.

It is made available under a CC-BY-NC-ND 4.0 International license .

antibody in this cohort was $11 \mathrm{mcg} / \mathrm{mL} .28$ In our study, the $\sim 45 \mathrm{mcg} / \mathrm{mL}$ Spike IgG antibody level in the COVID group at day 14 post vaccination suggests that broad immune activation e.g., Fcy receptor-mediated activity and T-cell activation was likely achieved. Moreover, this degree of immune activity in the COVID group occurred before the second injection.

The results of our study are in agreement with recent studies of the immune response to the mRNA vaccines most of which were cross-sectional in design and focused on the response to the $1^{\text {st }}$ injection. ${ }^{15-23}$ Like the present study, they also report more rapid increases in Spike IgG antibody after the first injection of an mRNA vaccine in subjects with prior COVID-19 than in infection-naïve subjects. Our study extended these observations by more precisely defining the time course of the Spike antibody response, i.e., onset, peak and rate of decay to both doses of an mRNA vaccine. We also assessed serum neutralizing activity.

Moreover, our data represent the first available set of time-dependent "normal" values for Spike IgG antibody induced by BNT162b2 in healthy subjects with and without prior COVID-19. Accordingly, our data can be used to assess the level of the anti-Spike antibody response to BNT162b2 in potentially immunocompromised individuals e.g., solid organ transplant recipients. ${ }^{35}$ Our data, therefore, may facilitate medical decision making in the care of individual patients.

An important public health implication of our study is that subjects with a prior history of SARS-CoV-2 infection / COVID-19 may not respond to a second dose of an mRNA vaccine and hence may not need it. In essence, the prior bout of COVID-19 may have provided sufficient immune stimulation such that the first dose of vaccine elicited a maximal or near maximal response. In fact, anecdotal reports in small numbers of subjects with prior SARS-CoV-2 - infection indicate that the $2^{\text {nd }}$ injection may cause a reduction in Spike IgG levels and decreases in circulating B memory and T-cells. ${ }^{19}$

In conclusion, the present study indicates that humoral responses to an mRNA vaccine are timedependent and differ in subjects with prior SARS-CoV-2 infection and infection - naïve subjects. Subjects with prior, generally moderate-severe COVID-19 disease achieve a rapid, maximal or near maximal level of humoral immunity after a single dose of a COVID mRNA vaccine. In fact, the humoral immune response to the second dose is greatly attenuated if not absent in subjects with prior COVID-19.

The possibility that a single dose of vaccine in subjects with prior COVID-19 is as efficacious as the 2 dose regimen in achieving a protective immune response has profound public health implications. It affords an opportunity to conserve millions of doses which could be used to help address the critical world-wide shortage of vaccine. This issue, however, will require a proper controlled trial in SARSCoV-2-infected individuals in which the protection against re-infection with recent variants achieved with 1 vaccine dose is compared with the current 2 dose regimen. 


\section{ACKNOWLEDGEMENTS}

The authors are grateful to the entire community of Temple University Hospital physicians, nurses, technicians and other health care workers who contributed considerable time over many months in support of this project. Their altruism and courage in the care of our patients with COVID-19 was a source of inspiration to us all.

We also wish to thank BEI Resources whose repeated, timely shipments of crucial reagents allowed us to carry out the assays on which this project was based.

The following reagents were obtained through BEI Resources, NIAID, NIH: Monoclonal Anti-SARS Coronavirus Recombinant Human IgG1, Clone CR3022 (produced in Nicotiana benthamiana), NR52392; SARS-Related Coronavirus 2, Wuhan-Hu-1 Spike-Pseudotyped Lentiviral Kit, NR-52948; Human Embryonic Kidney Cells (HEK-293T) Expressing Human Angiotensin-Converting Enzyme 2, HEK-293T-hACE2 Cell Line, NR-52511; Monoclonal Anti-SARS-Related Coronavirus 2 Spike Glycoprotein RBD-mFc Fusion Protein (produced in vitro), NR-53795. 
medRxiv preprint doi: https://doi.org/10.1101/2021.03.18.21253845; this version posted July 31, 2021. The copyright holder for this preprint (which was not certified by peer review) is the author/funder, who has granted medRxiv a license to display the preprint in perpetuity. It is made available under a CC-BY-NC-ND 4.0 International license .

Table 1. Subject Demographics

\begin{tabular}{|l|c|c|c|}
\hline & $\begin{array}{l}\text { COVID } \\
(\mathbf{n}=\mathbf{3 0})\end{array}$ & $\begin{array}{c}\text { Control } \\
(\mathbf{n}=\mathbf{3 1})\end{array}$ & $\begin{array}{c}\mathbf{p} \\
\text { value }\end{array}$ \\
\hline $\begin{array}{l}\text { Age (years) } \\
\text { Mean } \pm \text { SEM }\end{array}$ & $47 \pm 3$ & $45 \pm 2$ & 0.82 \\
\hline $\begin{array}{l}\text { Gender \% (n) } \\
\text { Males } \\
\text { Females }\end{array}$ & $\begin{array}{l}50(15) \\
50(15)\end{array}$ & $\begin{array}{l}52(16) \\
48(15)\end{array}$ & 0.85 \\
\hline $\begin{array}{l}\text { Ethnicity \% (n) } \\
\text { Caucasian } \\
\text { Asian } \\
\text { African-American }\end{array}$ & $\begin{array}{l}80(24) \\
10(3)\end{array}$ & $\begin{array}{l}77(24) \\
13(4) \\
10(3)\end{array}$ & 0.94 \\
\hline
\end{tabular}


medRxiv preprint doi: https://doi.org/10.1101/2021.03.18.21253845; this version posted July 31, 2021. The copyright holder for this preprint (which was not certified by peer review) is the author/funder, who has granted medRxiv a license to display the preprint in perpetuity. It is made available under a CC-BY-NC-ND 4.0 International license .

Table 2. SARS-CoV-2 Infection $(n=30)$

\begin{tabular}{|c|c|}
\hline Symptoms / Characteristics & n (\%) \\
\hline $\begin{array}{lll}\text { Nasopharyngeal } & \text { Swab } & \text { RT-PCR } \\
\text { Positive } & & \\
\end{array}$ & $26(87)$ \\
\hline Malaise & $19(63)$ \\
\hline Myalgia & $18(60)$ \\
\hline Headache & $15(50)$ \\
\hline Fever & $16(53)$ \\
\hline Cough & $13(43)$ \\
\hline Shortness of breath & $12(40)$ \\
\hline Chills & $9(30)$ \\
\hline Sinus Congestion & $5(17)$ \\
\hline Sore Throat & $5(17)$ \\
\hline Diarrhea & $5(17)$ \\
\hline Pneumonia & $4(13)$ \\
\hline Hospitalization & $2(7)$ \\
\hline None & $2(7)$ \\
\hline $\begin{array}{l}\text { Symptom Onset to Vaccine Interval } \\
\text { Mean } \pm \text { SEM (days) } \\
\text { Range }\end{array}$ & $\begin{array}{r}201 \pm 16 \\
25-332\end{array}$ \\
\hline
\end{tabular}


Table 3. Spike RBD lgG Antibody Levels (mcg protein / $\mathrm{mL}$ serum)

\begin{tabular}{|c|c|c|c|c|c|c|}
\hline Groups & Pre-Vaccine & Day 14 & Day 28 & Day 42 & Day 56 & Peak \\
\hline $\begin{array}{l}\text { COVID } \\
\text { mean } \pm 1 \text { SE } \\
\text { range }(\min -\max ) \\
\quad \mathbf{n}=\end{array}$ & $\begin{array}{c}10.7 \pm 4.1 \\
(0.7-82.3) \\
22\end{array}$ & $\begin{array}{c}45.6 \pm 6.0 \\
(4.6-145.5) \\
25\end{array}$ & $\begin{array}{c}56.7 \pm 6.4 \\
(14.9-184.5) \\
28\end{array}$ & $\begin{array}{c}48.7 \pm 6.0 \\
(16.4-168.0) \\
28\end{array}$ & $\begin{array}{c}38.7 \pm 4.9 \\
(13.7-126.8) \\
28\end{array}$ & $\begin{array}{c}59.6 \pm 6.4 \\
(23.9-184.5) \\
29\end{array}$ \\
\hline $\begin{array}{c}\text { Control } \\
\text { mean } \pm 1 \text { SE } \\
\text { range }(\min -\max ) \\
\quad \mathbf{n}=\end{array}$ & $\begin{array}{l}0 \pm 0.1 \\
(0.0-0.3) \\
22\end{array}$ & $\begin{array}{c}2.2 \pm 0.6 \\
(0.1-10.7) \\
26\end{array}$ & $\begin{array}{c}65.3 \pm 10.0 \\
(2.5-214.4) \\
29\end{array}$ & $\begin{array}{c}65.6 \pm 10.5 \\
(4.1-301.9) \\
31\end{array}$ & $\begin{array}{c}49.4 \pm 8.4 \\
(3.4-234.1) \\
31\end{array}$ & $\begin{array}{c}79.6 \pm 11.5 \\
(6.5-301.9) \\
29\end{array}$ \\
\hline${ }^{+} p$ value & $<0.003$ & $<0.0002$ & 0.39 & 0.10 & 0.30 & $<0.0002$ \\
\hline
\end{tabular}

+ for comparison of COVID vs control by Linear mixed effects regression 
medRxiv preprint doi: https://doi.org/10.1101/2021.03.18.21253845; this version posted July 31, 2021. The copyright holder for this preprint (which was not certified by peer review) is the author/funder, who has granted medRxiv a license to display the preprint in perpetuity. It is made available under a CC-BY-NC-ND 4.0 International license .

\section{FIGURE LEGENDS}

Figure 1. Spike RBD IgG antibody responses to the BNT162b2 vaccine in COVID (•) and control (•) groups. Upper Panel: Shows group mean \pm 1 SE responses. Vertical arrow indicates time of second vaccine injection. Note that the time course of Spike RBD IgG antibody response to vaccination was significantly different between COVID and control groups $(p<0.0001$; linear mixed effects model for repeated measures). Differences in Spike IgG antibody levels were significant prevaccine $(p<0.003)$ and at day $14\left({ }^{* *} p<0.0002\right)$. However, Spike IgG levels were similar at days 28,42 and 56 ( $p>0.10$ for all 3 comparisons). Sample size in the COVID group was: day 14 ( $n=25)$, day 28 $(n=28)$, day $42(n=28)$ and day $56(n=28)$; in the control group: day $14(n=26)$, day $28(n=29)$, day 42 $(n=31)$ and day $56(n=31)$. Lower Panel: Spike RBD IgG antibody responses to vaccine in individual COVID and control subjects. Note the considerable inter-subject variability in both groups.

Figure 2. Relationship between vaccine-induced peak Spike RBD IgG antibody and interval post onset SARS-CoV-2 symptoms (POS) in COVID subjects $(\mathbf{n}=\mathbf{2 7})$. There was no discernable relationship ( $R^{2}=0.01$ by linear regression). Of note, 2 of the 29 subjects in the COVID group were asymptomatic. Hence, no POS value is available.

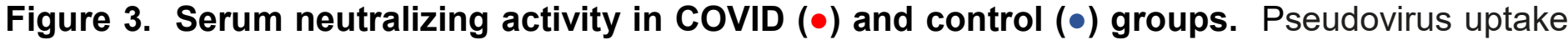
in HEK-293 ACE2 overexpressing cells was assessed from luciferase activity, i.e., relative light units(RLU), on the $\mathrm{Y}$ axis. Serum dilution is on the $\mathrm{X}$-axis. The $100 \%$ control value on the $\mathrm{Y}$ axis represents maximal virus uptake occurring in the absence of serum. IC 50 was calculated using sigmoidal 4 factor polynomial, non-linear regression

Data are shown pre-vaccination (upper) and day 14 (middle) and day 42 (lower panel) post $1^{\text {st }}$ vaccine dose. Pre-vaccine, neutralizing activity in the COVID group $(n=7)$ tended to be greater than in the control group $(n=7) \quad\left(\mathrm{IC}_{50} 7 \times 10^{-3}\right.$ vs $2 \times 10^{-2}$ dilution, respectively) but was not statistically significantly different ( $p=0.20$ by 2 -way ANOVA). At Day 14 post $1^{\text {st }}$ injection, neutralizing activity increased greatly in the COVID group $(n=21)$ but was unchanged in the control group $(n=21)\left(I_{50}=4\right.$ $\times 10^{-4}$ vs $1 \times 10^{-2}$ dilution, respectively; $p<0.03$ by 2-way ANOVA for comparison of the 2 groups). In contrast, at Day 42, neutralizing activity increased greatly in the control group ( $n=21)$ but only slightly in the COVID group $(n=21)\left(I C_{50}=3 \times 10^{-4}\right.$ vs $5 \times 10^{-4}$ dilution, respectively) and was again not statistically significantly different $(p=0.11$ for comparison of the 2 groups by 2-way ANOVA). For days 14 and 42, the same 21 COVID and 21 control subjects were studied, and for both groups each datapoint is the mean \pm SE for 3 pools of 7 subjects each.

Figure 4: Reactions to the $1^{\text {st }}$ and 2nd Pfizer BNT162b2 mRNA vaccine in COVID and control groups. Panel A: Prevalence and severity of systemic and local reactions. Dark color (red or blue) indicates reaction scores of $>6$ severity; light colors indicate scores $\leq 5$. Brackets indicate statistical comparisons across groups. Lines indicate comparisons within groups. Asterisk $\left(^{*}\right)$ indicates $p<0.05$; double asterisk $\left({ }^{* *}\right)$ indicates $p<0.01$; and cross $(\boldsymbol{t})$ indicates $p<0.001$. Panel B: Duration of systemic symptoms (Left) and frequency of medication use (Right) in COVID and control groups. 
medRxiv preprint doi: https://doi.org/10.1101/2021.03.18.21253845; this version posted July 31, 2021. The copyright holder for this preprint (which was not certified by peer review) is the author/funder, who has granted medRxiv a license to display the preprint in perpetuity.

It is made available under a CC-BY-NC-ND 4.0 International license .

Figure 1
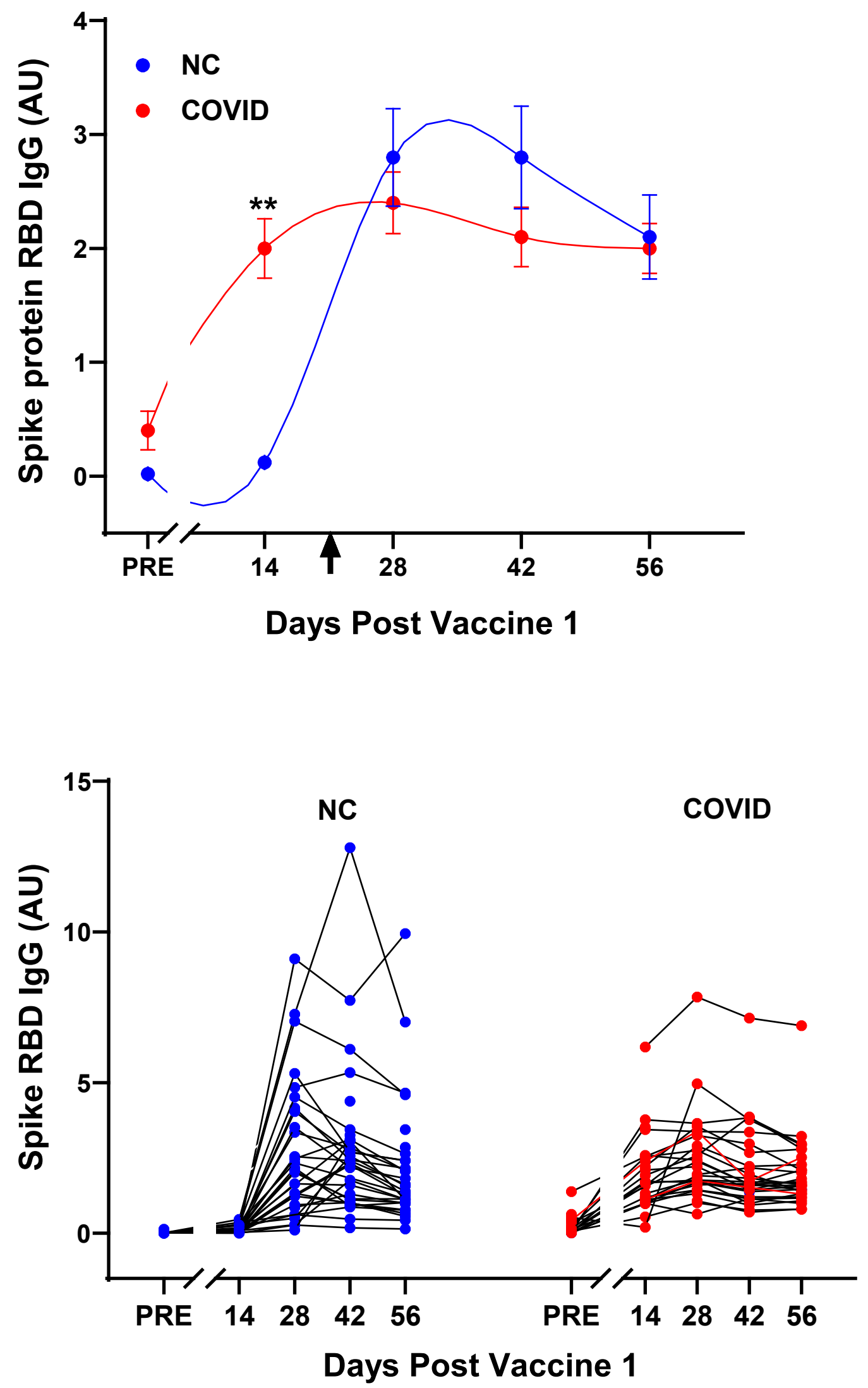
medRxiv preprint doi: https://doi.org/10.1101/2021.03.18.21253845; this version posted July 31, 2021. The copyright holder for this preprint (which was not certified by peer review) is the author/funder, who has granted medRxiv a license to display the preprint in perpetuity.

It is made available under a CC-BY-NC-ND 4.0 International license .

\section{Figure 2}

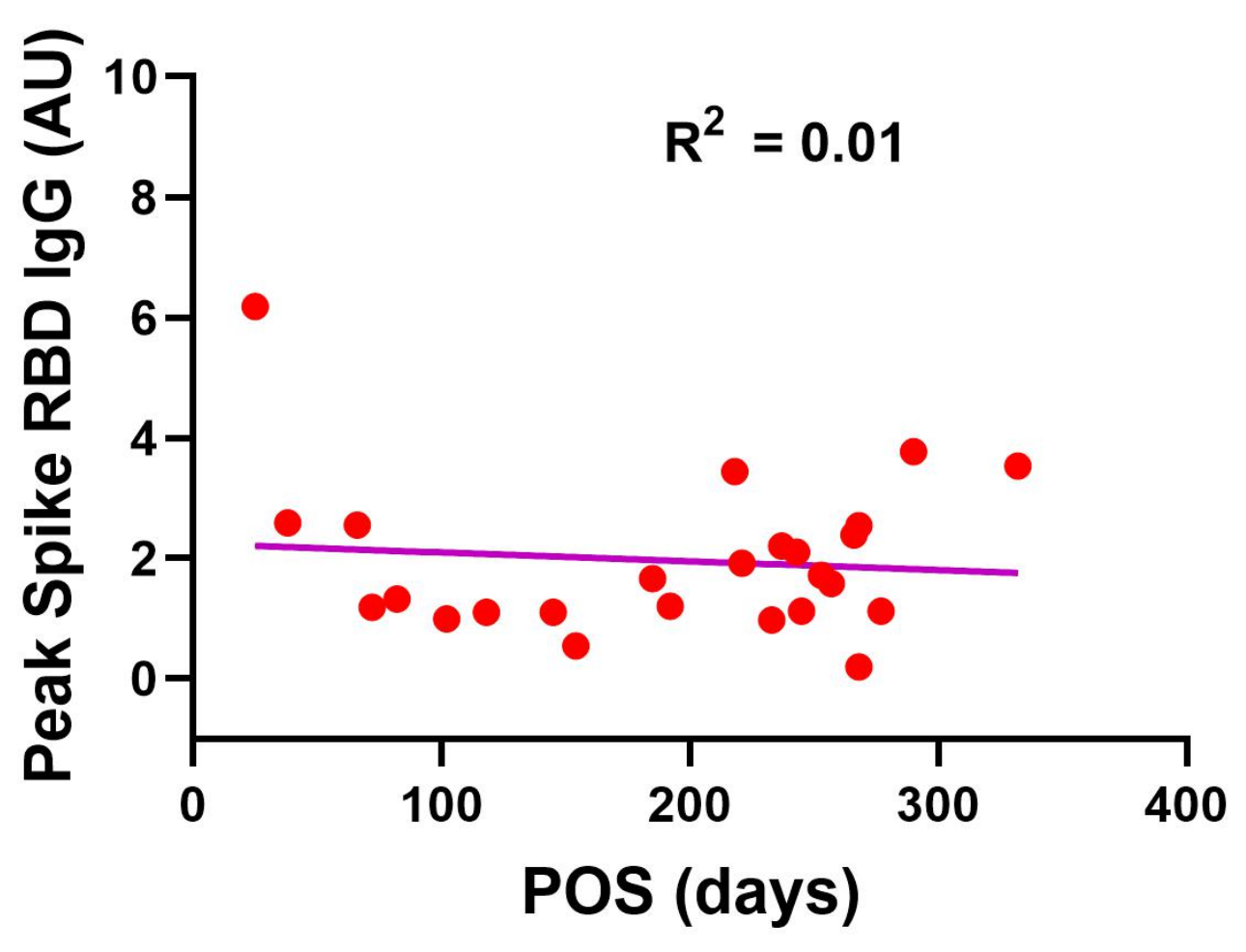


medRxiv preprint doi: https://doi.org/10.1101/2021.03.18.21253845; this version posted July 31, 2021. The copyright holder for this preprint (which was not certified by peer review) is the author/funder, who has granted medRxiv a license to display the preprint in perpetuity.

\section{It is made available under a CC-BY-NC-ND 4.0 International license .}

\section{Figure 3}
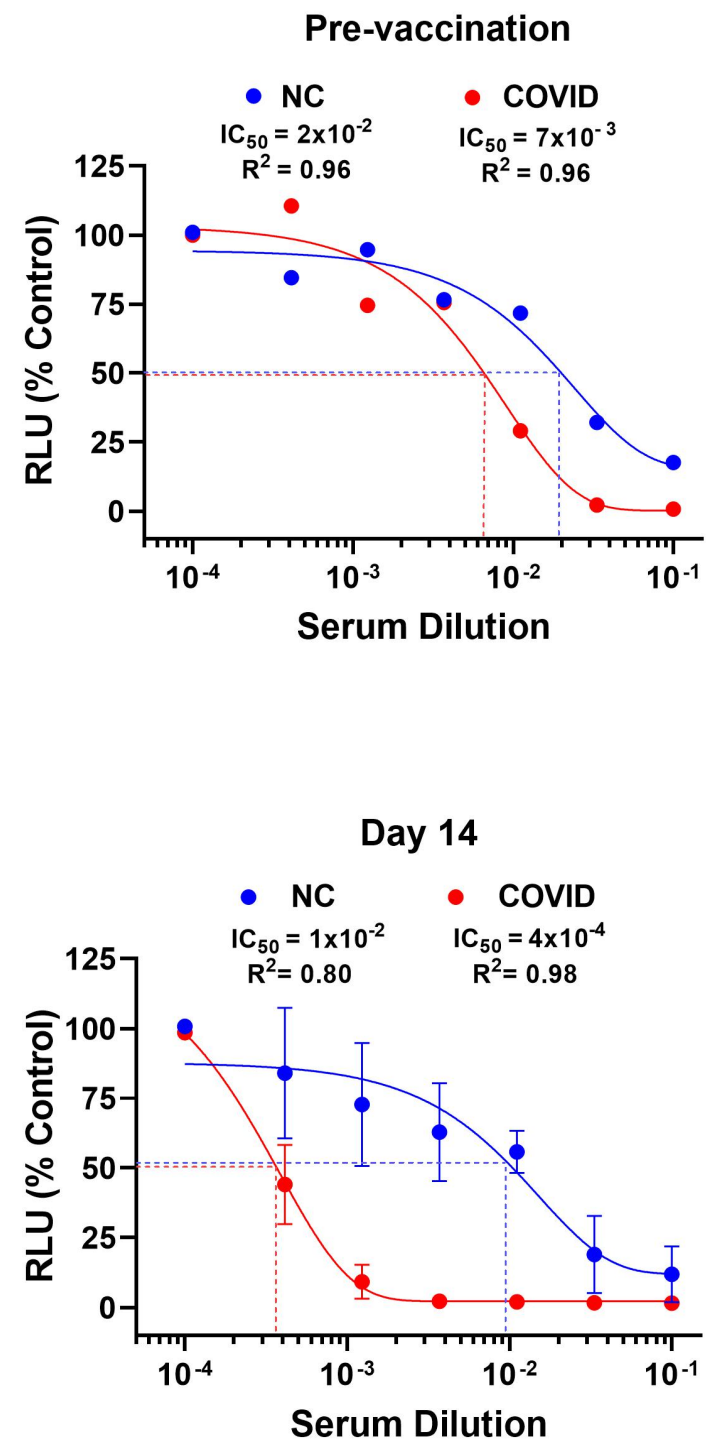

Day 42

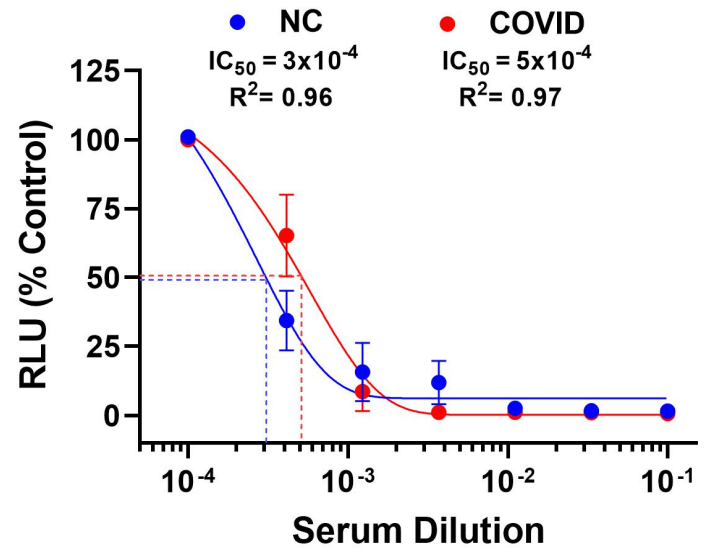


medRxiv preprint doi: https://doi.org/10.1101/2021.03.18.21253845; this version posted July 31, 2021. The copyright holder for this preprint (which was not certified by peer review) is the author/funder, who has granted medRxiv a license to display the preprint in perpetuity.

It is made available under a CC-BY-NC-ND 4.0 International license .

Figure 4

Panel A

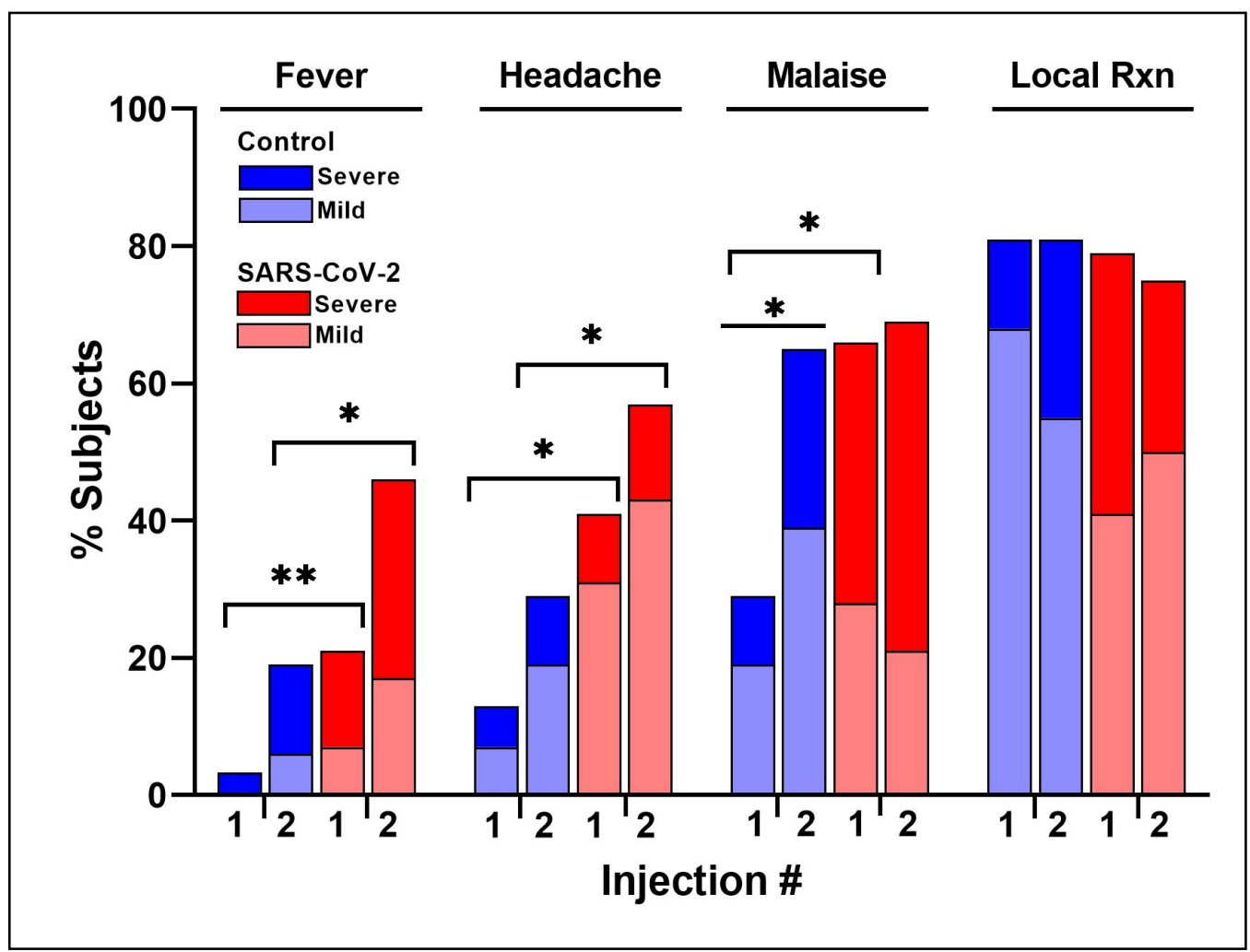

Panel B

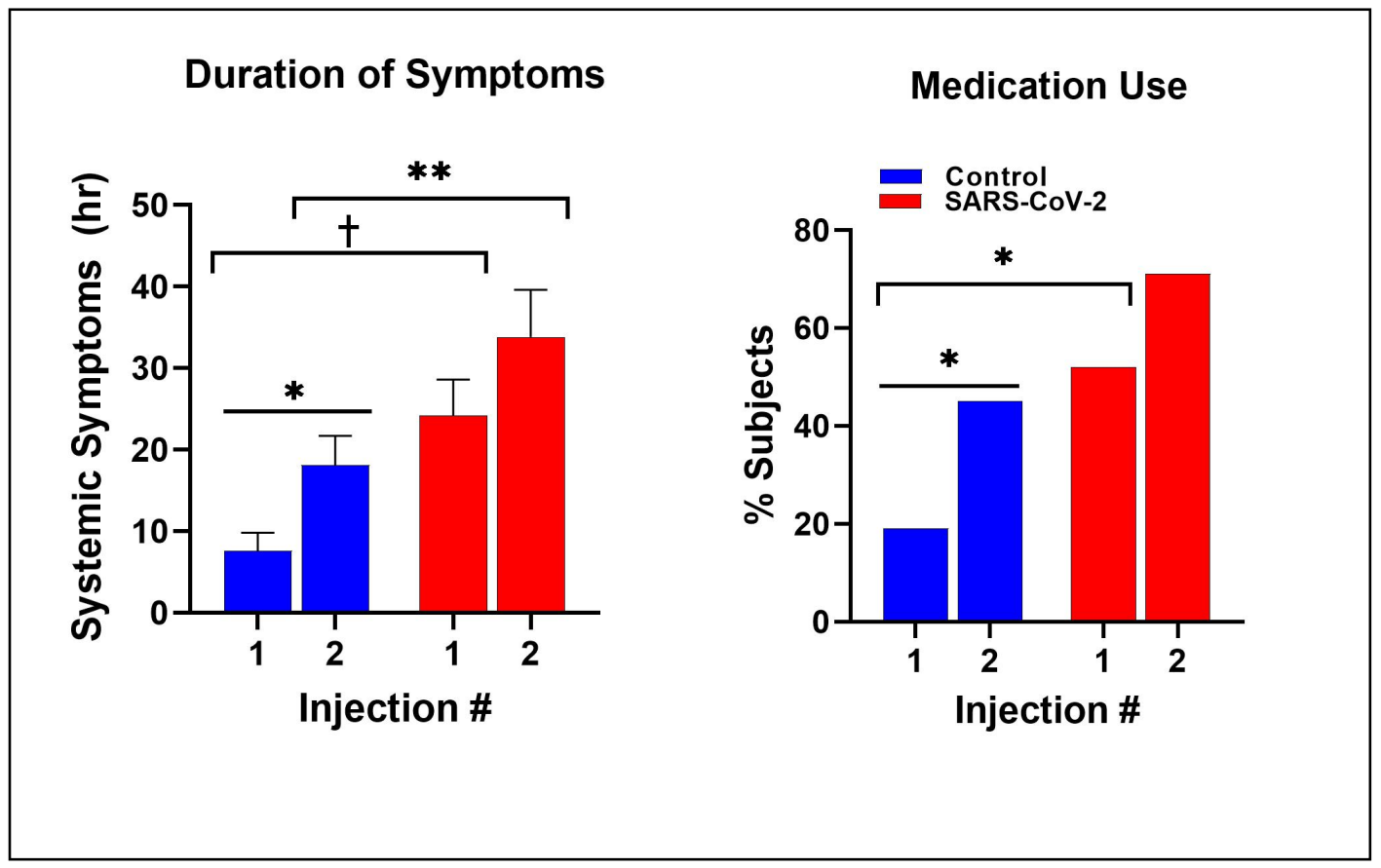


medRxiv preprint doi: https://doi.org/10.1101/2021.03.18.21253845; this version posted July 31, 2021. The copyright holder for this preprint (which was not certified by peer review) is the author/funder, who has granted medRxiv a license to display the preprint in perpetuity. It is made available under a CC-BY-NC-ND 4.0 International license .

\section{SUPPLEMENT}

\section{METHODS}

\section{Neutralization Assay}

Serum neutralization assays were performed as previously described by Crawford et al using luciferaseexpressing lentiviral particles pseudotyped for the SARS-CoV-2 spike protein and HEK-293T cells overexpressing the ACE2 receptor (HEK-293T-hACE2). ${ }^{30}$

Pseudovirus preparation - Pseudotyped lentivirus was generated in HEK-293T cells transfected simultaneously with the following: helper plasmids encoding for Gag and Pol, Tat1b, and Rev1b; lentiviral backbone plasmid encoding for Luc2 and ZsGreen; and plasmid encoding the Wuhan-Hu-1 strain of SARSCoV-2 Spike glycoprotein (Lentiviral Kit, BEI Resources, \#NR-52948). After $72 \mathrm{hrs,} \mathrm{the} \mathrm{culture} \mathrm{supernatant}$ containing pseudovirus was harvested, syringe-filtered $(0.45 \mu \mathrm{m})$, and stored at $-80^{\circ} \mathrm{C}$.

Neutralization assay - HEK-293T-hACE2 cells (80,000 cells/well; BEI Resources, \#NR-52511) were cultured in white-walled microplates for $24 \mathrm{hr}$. Pseudovirus entry was assessed from luciferase activity using a GloMax Discover luminometer (Promega Corp., \#GM3000) and Bright-Glo reagent (Promega, \#E2610). Initially, to determine optimum conditions for the assay, the signal generated by various pseudovirus dilutions was assessed in the absence of serum (Fig. S3). A 10x-dilution of pseudovirus stock (plus $5 \mu \mathrm{g} / \mathrm{mL}$ polybrene, EMD Millipore Corp., \#TR-2003-G) which yielded an RLU of 25,000 was used throughout. Negative controls i.e., supernatants from HEK-293T cells transfected with carrier DNA only (Promega, \#E4881) (data not shown), or with a lentiviral plasmid lacking the Spike glycoprotein, yielded RLU values less than $0.2 \%$ of the undiluted pseudovirus (Fig. S3). For the neutralization assay itself, 7-point serial serum dilutions were incubated with pseudovirus for $1 \mathrm{hr}$ at $37^{\circ} \mathrm{C}$ in a separate sterile plate. The serum-pseudovirus mixtures were then incubated with HEK-293T-hACE2 cells for $48 \mathrm{hr}$ at $37^{\circ} \mathrm{C}$. A potent neutralizing Spike RBD IgG antibody (BEI Resources, \#NR-53795) was used as a positive control in each run (Fig. S4).

Experimental Design and Data Analysis - Neutralization assays were performed pre-vaccination and at days 14 and 42 post $1^{\text {st }}$ injection of vaccine. Individual serum samples (50 $\mu \mathrm{L} /$ subject) were pooled with 7 subjects per pool in both COVID and control groups. On days 14 and 42, data points for both groups are the mean \pm SE of 3 pools of the same 21 COVID and 21 control subjects. In contrast, the pre-vaccination timepoint was a single pool for each group.

Maximal pseudovirus uptake by HEK cells in the absence of serum was taken as $100 \%$ of control. IC $_{50}$ i.e., $50 \%$ inhibition of pseudovirus entry, was calculated using sigmoidal 4 factor polynomial, non-linear regression (GraphPad Prism version 9). 
medRxiv preprint doi: https://doi.org/10.1101/2021.03.18.21253845; this version posted July 31, 2021. The copyright holder for this preprint (which was not certified by peer review) is the author/funder, who has granted medRxiv a license to display the preprint in perpetuity. It is made available under a CC-BY-NC-ND 4.0 International license .

\section{FIGURE LEGENDS}

Figure S1. Violin plots showing pre-vaccination serum Spike RBD IgG antibody (left) and nucleocapsid IgG antibody (right) in individual $\operatorname{COVID}(\bullet, n=22)$ and control $(\mathrm{NC} \bullet, \mathrm{n}=22)$ subjects. Spike RBD IgG $(p<0.01)$ and nucleocapsid IgG $(p<0.003)$ antibody levels were significantly higher in the COVID compared to control groups prior to vaccination. Historical control samples (HC-•; $n=57$ ) were archived prior to the COVID19 pandemic i.e., 2008. Horizontal dashed line demarcates 4 standard deviations from the mean of the historical controls.

Figure S2. Nucleocapsid IgG antibody in COVID (•) and control (•) groups following the Pfizer BNT162b2 vaccine. Upper Panel: Shows group mean \pm 1 SE responses. Sample size for COVID group was: day $14(n=16)$, day $42(n=18)$. Sample size for control group was: day $14(n=16)$, day $42(n=17)$. Lower Panel: Individual COVID and control subjects. Note that nucleocapsid IgG antibody is undetectable in the control group and falls over time post vaccination in the COVID group.

Figure S3. Uptake of pseudotyped SARS-CoV-2 lentivirus into HEK293T-ACE2 cells. Intact pseudotyped lentivirus $(\bullet)$ uptake shown as luciferase activity on the $Y$ axis (relative light units - RLU) was assessed in the absence of serum. Pseudovirus dilutions are shown on the $X$ axis. Lentivirus lacking SARSCoV-2 Spike protein ( $($ ) was used as an inactive, negative control. Data are Group mean \pm 1 SE from multiple wells (1 experiment representative of 3 ). Note that intact pseudovirus diluted 10X from stock generated a signal 500 fold greater than that produced by the inactive pseudovirus. Inset - Western blot showing marked increase in ACE2 receptor expression in 293T-ACE2 vs native 293T cells.

Figure S4. Effect of neutralizing Spike IgG antibody on pseudotyped SARS-CoV-2 lentivirus entry into HEK293T-ACE2 cells. Note that positive control Spike RBD neutralizing antibody (BEI \#NR-53795) strongly inhibited pseudovirus uptake $\left(\mathrm{IC}_{50}=2.8 \mathrm{ng} / \mathrm{mL}\right)$. Data are mean $\pm 1 \mathrm{SE}$ of 4 experiments. 
medRxiv preprint doi: https://doi.org/10.1101/2021.03.18.21253845; this version posted July 31, 2021. The copyright holder for this preprint (which was not certified by peer review) is the author/funder, who has granted medRxiv a license to display the preprint in perpetuity. It is made available under a CC-BY-NC-ND 4.0 International license.

\section{Figure S1}

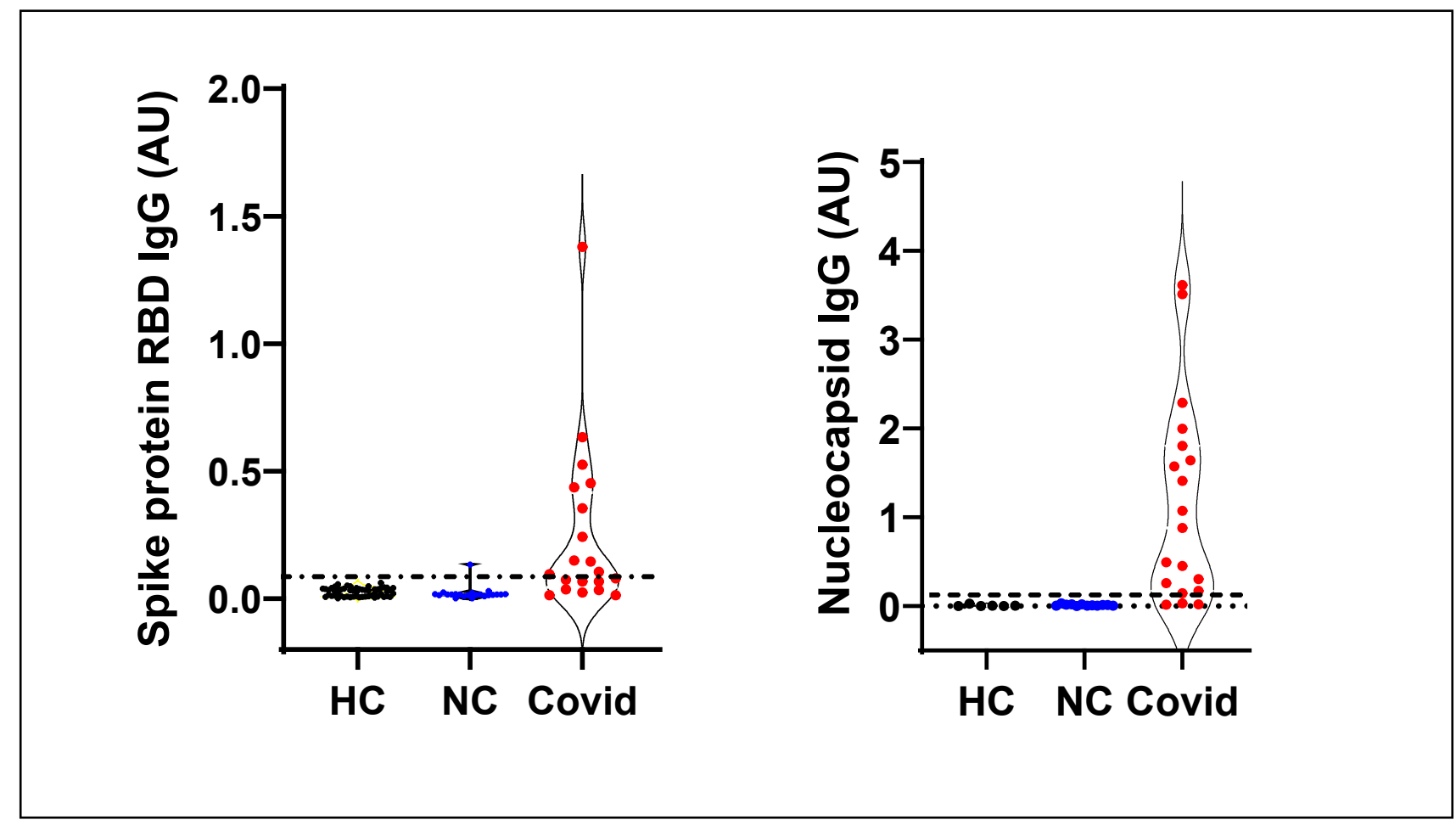




\section{Figure S2}

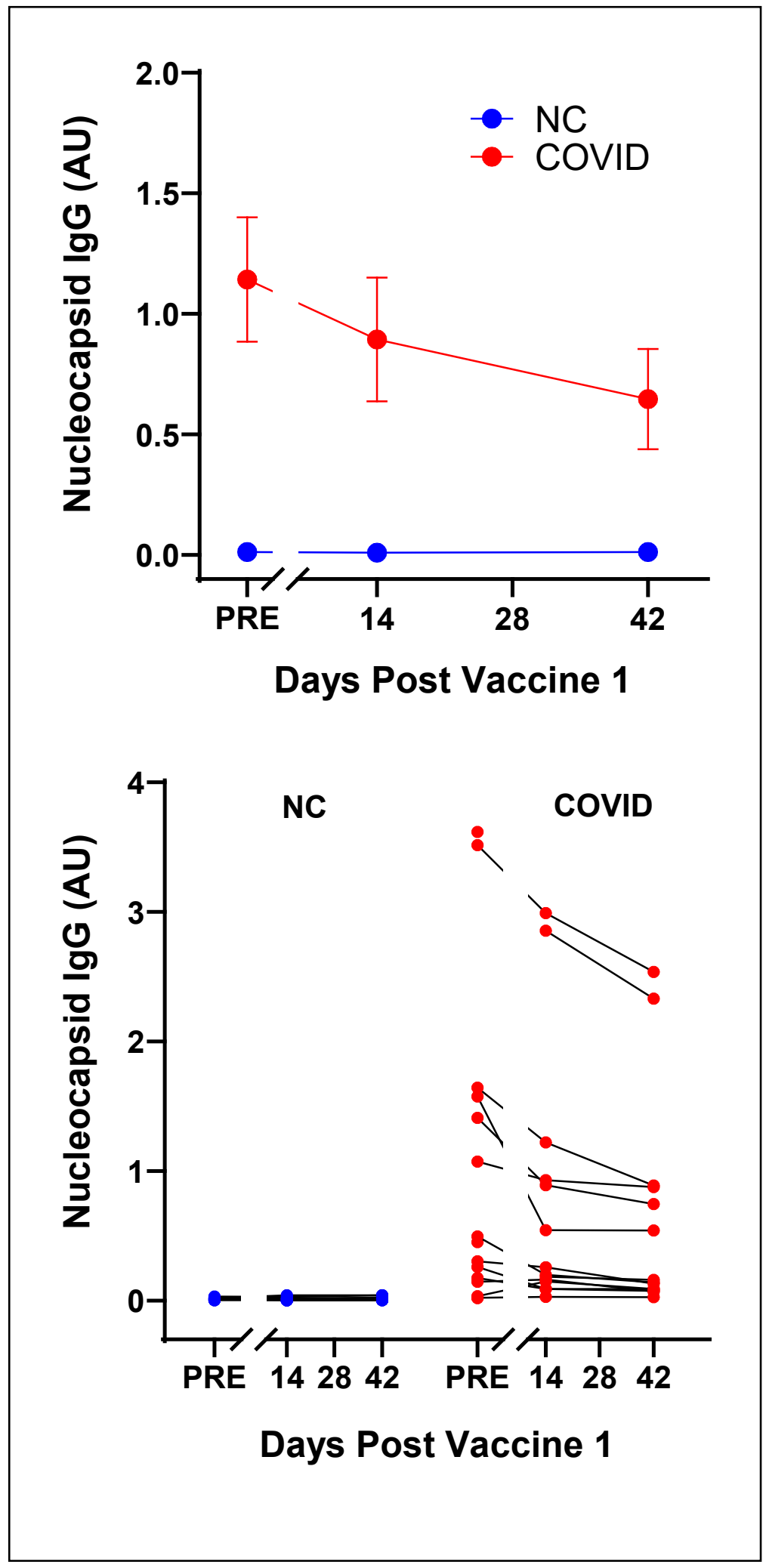


medRxiv preprint doi: https://doi.org/10.1101/2021.03.18.21253845; this version posted July 31, 2021. The copyright holder for this preprint (which was not certified by peer review) is the author/funder, who has granted medRxiv a license to display the preprint in perpetuity. It is made available under a CC-BY-NC-ND 4.0 International license .

\section{Figure S3}

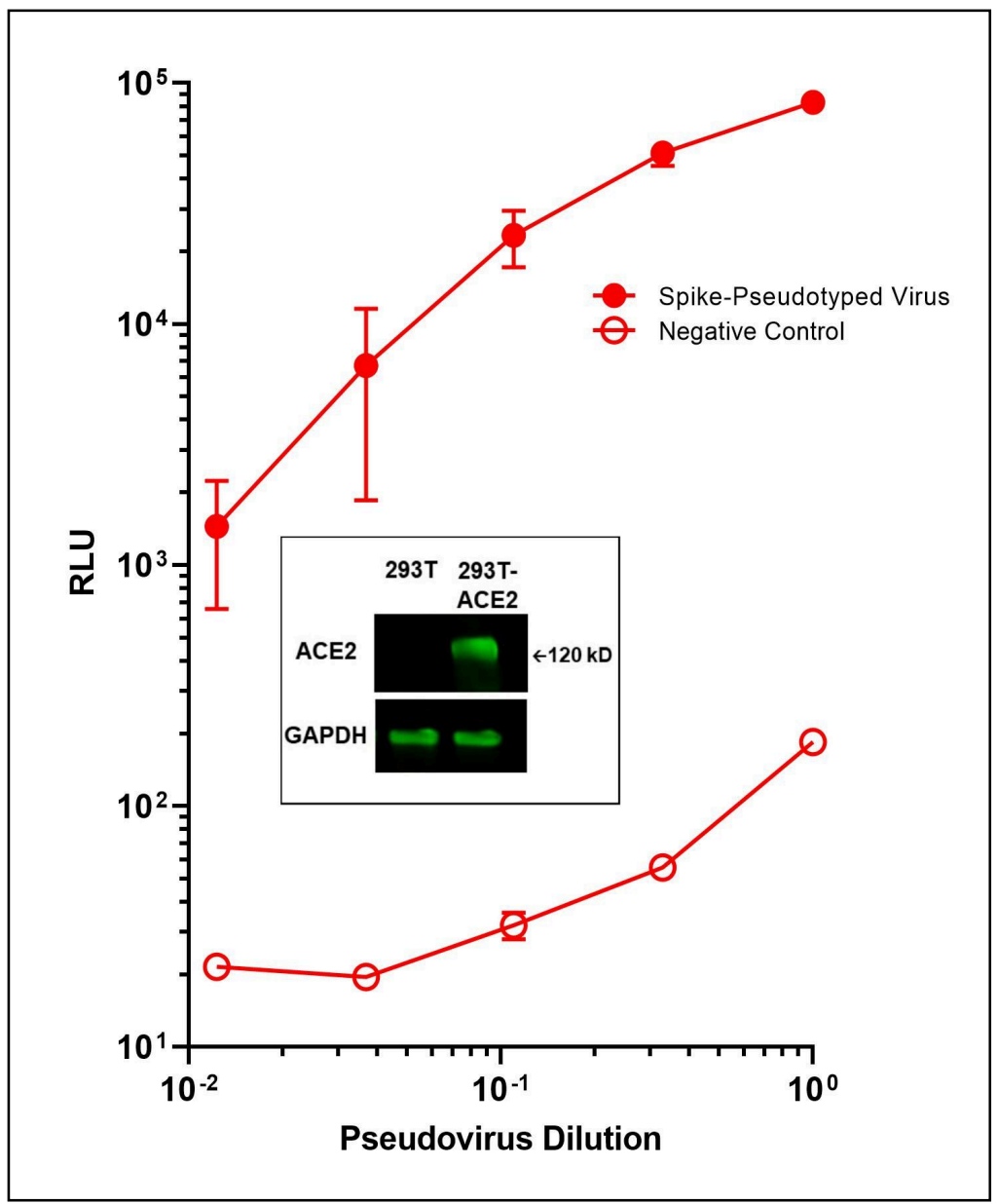


medRxiv preprint doi: https://doi.org/10.1101/2021.03.18.21253845; this version posted July 31, 2021. The copyright holder for this preprint (which was not certified by peer review) is the author/funder, who has granted medRxiv a license to display the preprint in perpetuity. It is made available under a CC-BY-NC-ND 4.0 International license .

\section{Figure S4}

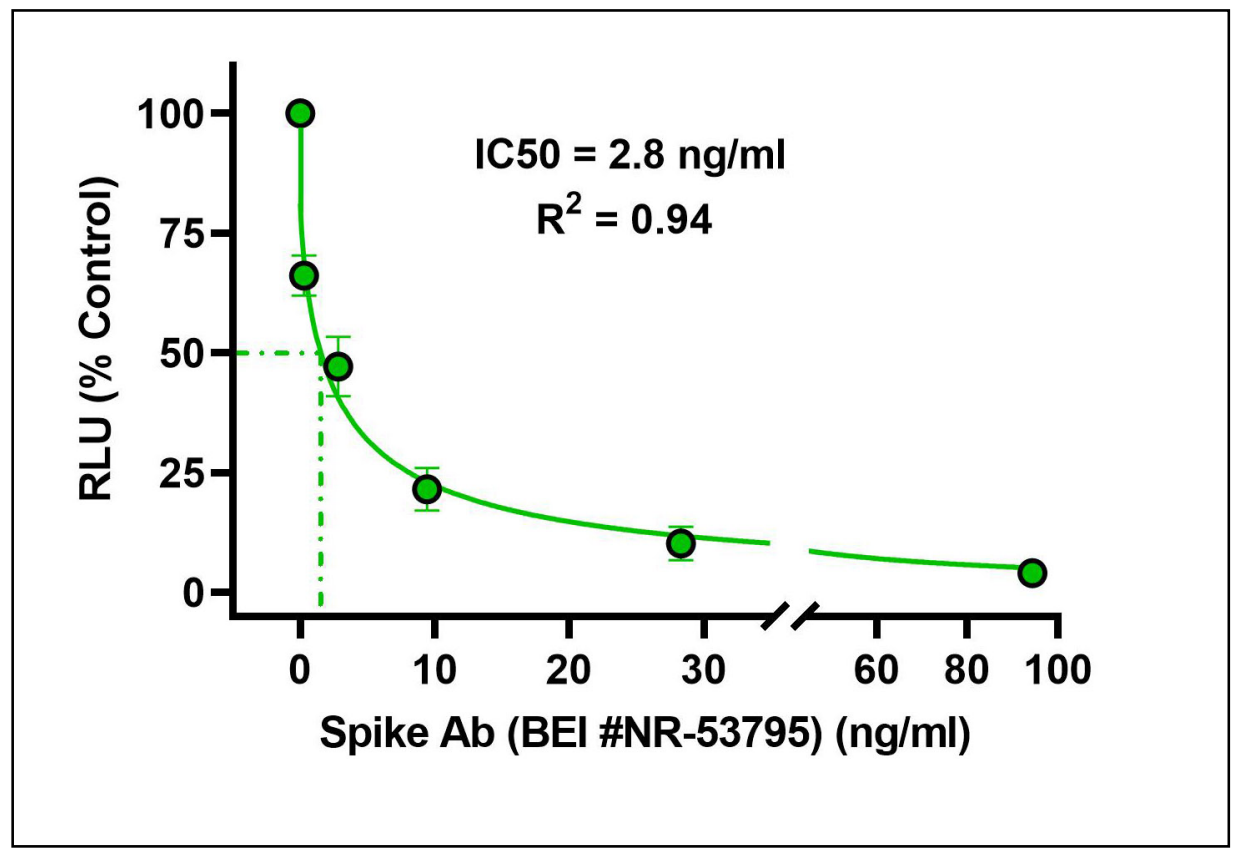


medRxiv preprint doi: https://doi.org/10.1101/2021.03.18.21253845; this version posted July 31, 2021. The copyright holder for this preprint (which was not certified by peer review) is the author/funder, who has granted medRxiv a license to display the preprint in perpetuity. It is made available under a CC-BY-NC-ND 4.0 International license .

\section{REFERENCES}

1. Anderson E. J RNG, m, R. N. A. Study Group, et al. Safety and Immunogenicity of SARS-CoV-2 mRNA-1273 Vaccine in Older Adults. N Engl J Med 2020;383(25):2427-2438. DOI: 10.1056/NEJMoa2028436.

2. Baden LR, El Sahly, H. M, Cove Study Group, et al. Efficacy and Safety of the mRNA-1273 SARSCoV-2 Vaccine. N Engl J Med 2021;384(5):403-416. DOI: 10.1056/NEJMoa2035389.

3. Dagan N BN, et al. BNT162b2 mRNA Covid-19 Vaccine in a Nationwide Mass Vaccination Setting. N Engl J Med 2021. DOI: 10.1056/NEJMoa2101765.

4. Polack F. P TSJ, C. Clinical Trial Group, et al. Safety and Efficacy of the BNT162b2 mRNA Covid-19 Vaccine. N Engl J Med 2020;383(27):2603-2615. DOI: 10.1056/NEJMoa2034577.

5. Walsh E. E FRW, J, et al. Safety and Immunogenicity of Two RNA-Based Covid-19 Vaccine Candidates. N Engl J Med 2020;383(25):2439-2450. DOI: 10.1056/NEJMoa2027906.

6. CDC. Interim Clinical Considerations for mRNA COVID-19 Vaccines Currently Authorized in the United States. (https://www.cdc.gov/vaccines/covid-19/info-by-product/clinical-considerations.html).

7. Dan J. M MJ, et al. Immunological memory to SARS-CoV-2 assessed for up to 8 months after infection. Science 2021;371(6529). DOI: 10.1126/science.abf4063.

8. Turner JS, Kim W, Kalaidina E, et al. SARS-CoV-2 infection induces long-lived bone marrow plasma cells in humans. Nature 2021;595(7867):421-425. DOI: 10.1038/s41586-021-03647-4.

9. Wajnberg $A A F$, et al. Robust neutralizing antibodies to SARS-CoV-2 infection persist for months. Science 2020;370(6521):1227-1230. DOI: 10.1126/science.abd7728.

10. Gaebler C, Wang Z, Lorenzi JCC, et al. Evolution of antibody immunity to SARS-CoV-2. Nature 2021;591(7851):639-644. DOI: 10.1038/s41586-021-03207-w.

11. Le Bert N TAT, et al. SARS-CoV-2-specific T cell immunity in cases of COVID-19 and SARS, and uninfected controls. Nature 2020;584(7821):457-462. DOI: 10.1038/s41586-020-2550-z.

12. Lumley S. F ODD, Oxford University Hospitals Staff Testing Group, et al. Antibody Status and Incidence of SARS-CoV-2 Infection in Health Care Workers. N Engl J Med 2021;384(6):533-540. DOI: 10.1056/NEJMoa2034545.

13. Sheehan MM, Reddy AJ, Rothberg MB. Reinfection Rates among Patients who Previously Tested Positive for COVID-19: a Retrospective Cohort Study. Clin Infect Dis 2021. DOI: 10.1093/cid/ciab234.

14. Addetia A CKHD, et al. Neutralizing Antibodies Correlate with Protection from SARS-CoV-2 in Humans during a Fishery Vessel Outbreak with a High Attack Rate. J Clin Microbiol 2020;58(11). DOI: 10.1128/JCM.02107-20.

15. Ebinger JE, Fert-Bober J, Printsev I, et al. Antibody responses to the BNT162b2 mRNA vaccine in individuals previously infected with SARS-CoV-2. Nat Med 2021;27(6):981-984. DOI: 10.1038/s41591021-01325-6.

16. Gobbi F, Buonfrate D, Moro L, et al. Antibody Response to the BNT162b2 mRNA COVID-19 Vaccine in Subjects with Prior SARS-CoV-2 Infection. Viruses 2021;13(3). DOI: 10.3390/v13030422. 
medRxiv preprint doi: https://doi.org/10.1101/2021.03.18.21253845; this version posted July 31, 2021. The copyright holder for this preprint (which was not certified by peer review) is the author/funder, who has granted medRxiv a license to display the preprint in perpetuity. It is made available under a CC-BY-NC-ND 4.0 International license .

17. Goel RR, Apostolidis SA, Painter MM, et al. Distinct antibody and memory B cell responses in SARSCoV-2 naive and recovered individuals following mRNA vaccination. Sci Immunol 2021;6(58). DOI: 10.1126/sciimmunol.abi6950.

18. Krammer F SK, et al. Antibody Responses in Seropositive Persons after a Single Dose of SARS-CoV-2 mRNA Vaccine. N Engl J Med 2021. DOI: 10.1056/NEJMc2101667.

19. Levi R, Azzolini E, Pozzi C, et al. One dose of SARS-CoV-2 vaccine exponentially increases antibodies in individuals who have recovered from symptomatic COVID-19. J Clin Invest 2021;131(12). DOI: 10.1172/JCl149154.

20. Manisty C OAD, et al. Antibody response to first BNT162b2 dose in previously SARS-CoV-2-infected individuals. Lancet 2021. DOI: 10.1016/S0140-6736(21)00501-8.

21. Mazzoni A, Di Lauria N, Maggi $L$, et al. First-dose mRNA vaccination is sufficient to reactivate immunological memory to SARS-CoV-2 in subjects who have recovered from COVID-19. J Clin Invest 2021;131(12). DOI: 10.1172/JCI149150.

22. Prendecki M CC, et al. Effect of previous SARS-CoV-2 infection on humoral and T-cell responses to single-dose BNT162b2 vaccine. Lancet 2021. DOI: 10.1016/S0140-6736(21)00502-X.

23. Saadat S, Rikhtegaran Tehrani Z, Logue J, et al. Binding and Neutralization Antibody Titers After a Single Vaccine Dose in Health Care Workers Previously Infected With SARS-CoV-2. JAMA 2021;325(14):1467-1469. DOI: 10.1001/jama.2021.3341.

24. Marc GP, Alvarez-Paggi D, Polack FP. Mounting evidence for immunizing previously infected subjects with a single dose of SARS-CoV-2 vaccine. J Clin Invest 2021;131(12). DOI: 10.1172/JCI150135.

25. Chapin-Bardales J, Gee J, Myers T. Reactogenicity Following Receipt of mRNA-Based COVID-19 Vaccines. JAMA 2021;325(21):2201-2202. DOI: 10.1001/jama.2021.5374.

26. Indenbaum V, Koren R, Katz-Likvornik S, et al. Testing IgG antibodies against the RBD of SARS-CoV-2 is sufficient and necessary for COVID-19 diagnosis. PLoS One 2020;15(11):e0241164. DOI: 10.1371/journal.pone.0241164.

27. Oved K, Olmer L, Shemer-Avni Y, et al. Multi-center nationwide comparison of seven serology assays reveals a SARS-CoV-2 non-responding seronegative subpopulation. EClinicalMedicine 2020;29:100651. DOI: 10.1016/j.eclinm.2020.100651.

28. Bartsch Y. C FS, et al. Discrete SARS-CoV-2 antibody titers track with functional humoral stability. Nat Commun 2021;12(1):1018. DOI: 10.1038/s41467-021-21336-8.

29. Roy V, Fischinger S, Atyeo C, et al. SARS-CoV-2-specific ELISA development. J Immunol Methods 2020;484-485:112832. DOI: 10.1016/j.jim.2020.112832.

30. Crawford K. H. D ER, et al. Protocol and Reagents for Pseudotyping Lentiviral Particles with SARSCoV-2 Spike Protein for Neutralization Assays. Viruses 2020;12(5). DOI: 10.3390/v12050513.

31. Schmidt F, Weisblum Y, Muecksch F, et al. Measuring SARS-CoV-2 neutralizing antibody activity using pseudotyped and chimeric viruses. J Exp Med 2020;217(11). DOI: 10.1084/jem.20201181.

32. Plotkin S. Vaccines: Correlates of vaccine-induced immunity. Clin Infect Dis 2008;47(3):401-9. DOI: $10.1086 / 589862$.

33. Klein S. L JA, Pekosz A. The $X s$ and $Y$ of immune responses to viral vaccines. Lancet Infect Dis 2010;10(5):338-49. DOI: 10.1016/S1473-3099(10)70049-9. 
medRxiv preprint doi: https://doi.org/10.1101/2021.03.18.21253845; this version posted July 31, 2021. The copyright holder for this preprint

(which was not certified by peer review) is the author/funder, who has granted medRxiv a license to display the preprint in perpetuity.

It is made available under a CC-BY-NC-ND 4.0 International license.

34. Krammer F, Simon V. Serology assays to manage COVID-19. Science 2020;368(6495):1060-1061. DOI: 10.1126/science.abc1227.

35. Boyarsky BJ, Werbel WA, Avery RK, et al. Antibody Response to 2-Dose SARS-CoV-2 mRNA Vaccine Series in Solid Organ Transplant Recipients. JAMA 2021;325(21):2204-2206. DOI: 10.1001/jama.2021.7489.

36. Baum A AD, et al. REGN-COV2 antibodies prevent and treat SARS-CoV-2 infection in rhesus macaques and hamsters. Science 2020;370(6520):1110-1115. DOI: 10.1126/science.abe2402.

37. Hansen J BA, et al. Studies in humanized mice and convalescent humans yield a SARS-CoV-2 antibody cocktail. Science 2020;369(6506):1010-1014. DOI: 10.1126/science.abd0827.

38. Long Q. X LBZ, et al. Antibody responses to SARS-CoV-2 in patients with COVID-19. Nat Med 2020;26(6):845-848. DOI: 10.1038/s41591-020-0897-1. 